\title{
The response of Monoterpenes to Different Enzyme Preparations in Gewürztraminer (Vitis vinifera L.) Wines
}

\author{
D. Rusjan ${ }^{1 *}$, M. Strlič², T. Košmerl ${ }^{2}$ and H. Prosen ${ }^{3}$
}

(1) Institute for Horticulture, Biotechnical Faculty, University of Ljubljana, Jamnikarjeva 101, SI-1000 Ljubljana, Slovenia

(2) Department of Food Science and Technology, Biotechnical Faculty, University of Ljubljana, Jamnikarjeva 101, SI-1000 Ljubljana, Slovenia

(3) Faculty of Chemistry and Chemical Technology, University of Ljubljana, Aškerčeva 5, Ljubljana, Slovenia

Submitted for publication: December 2008

Accepted for publication: May 2009

Keywords: Monoterpene; pectolytic enzyme; glucosidase; aroma; Gewürztraminer

\begin{abstract}
The $\alpha$-terpineol, linalool, nerol and geraniol, which are the main aromatic monoterpenes in the grapevine variety Gewürztraminer, were determined in the grapes, must and wine after treatment with six different pectolytic enzymes [Lallzyme- $\beta$ ('Lall'); Rohavin VR-C ('VRX'), Rohapect D5L ('D5L'), Rohavin MX ('MX'), Rohapect VRC ('VRC'), Endozym cultivar A ('Cult. A')], and after treatment with $\beta$-glucosidase ( $\beta G$, EC 3.2.1.21). The concentrations of monoterpenic compounds were determined by solid-phase microextraction (SPME) and GC-MS. The most abundant monoterpene in the grapes of Gewürztraminer was geraniol $(66.7 \mu \mathrm{g} / \mathrm{L})$, followed by nerol $(13.3 \mu \mathrm{g} / \mathrm{L}), \alpha$-terpineol $(7.8 \mu \mathrm{g} / \mathrm{L})$ and finally linalool $(3.3 \mu \mathrm{g} / \mathrm{L})$. Gewürztraminer wine from must treated with the Lall enzyme preparation was the most aromatic, which was also confirmed by chemical and sensory analysis in which the concentrations of nerol $(45.9 \mu \mathrm{g} / \mathrm{L})$, geraniol $(31.8 \mu \mathrm{g} / \mathrm{L}), \alpha$-terpineol $(10.5 \mu \mathrm{g} / \mathrm{L})$ and linalool $(6.1 \mu \mathrm{g} / \mathrm{L})$ were determined. The wines produced from must treated chemically with enzymes showed higher concentrations of many of the monoterpene compounds compared to the control, although the sensorial analysis did not affirm this convincingly.
\end{abstract}

In the last few decades, the demand for young white wines with a fresh and fruity aroma has increased. Aroma compounds play an important role in grape and wine, because they make a major contribution to the quality of the product. These compounds are present as free volatiles, which contribute directly to odour and non-volatile sugar-bound glycosidic conjugates. The main groups of aroma compounds are the aglycone moieties of glycosides, including terpenes, straight-chain alcohols, benzene derivates, C13 norisoprenoids and volatile phenols, where the sugar part is represented by glucose or disaccharides (Günata et al., 1985; Sánchez-Palomo et al., 2005; Prosen et al., 2007).

Aroma precursors of grapes and wines were studied intensively, in terms of the influence of various biological (Sánchez-Palomo et al., 2005; Prosen et al., 2007), ecological (Smart \& Robinson, 1991; Bureau et al., 2000; Miklósy \& Kerény, 2004; Sala et al., 2004; Peyrot des Gachons et al., 2005), biotechnological (Hernández et al., 2002; Swiegers et al., 2005; Comuzzo et al., 2006; Piñeiro et al., 2006; Chalier et al., 2007), physical-chemical (Darriet et al., 2001; Peyrot des Gechous et al., 2005; SánchezPalomo et al., 2007) and technological factors (Spillman et al., 2004; Francis \& Newton, 2005; Swiegers et al., 2005; Comuzzo et al., 2006; Chalier et al., 2007; Košmerl et al., 2008).

Aroma precursors are located mostly in the berry skin (Wilson et al., 1986; Bayonove, 1993; Mateo \& Jimenez, 2000; Prosen et al., 2007), so the must versus skin contact technique has been proposed to increase the aroma of white wines and enhance the varietal characters (Maicas \& Mateo, 2005; Prosen et al., 2007).
The volatile compounds from glycosides can be released by acid and enzymatic hydrolysis. Acid hydrolysis of terpene glycosides can produce changes in the monoterpenols, which could be transformed in other compounds. Enzymatic hydrolysis is a more interesting process in winemaking because its product causes enhancement of the more 'natural' flavour in wine (Cabaroglu et al., 2003; Maicas \& Mateo, 2005; Prosen et al., 2007; Valcárcel \& Palacios, 2008). The major enzyme groups in winemaking are oxidoreductase, pectinase, protease and $\beta$-glycosidase. Currently, aroma release is enhanced using commercial enzyme preparations of fungal origin, mainly Aspergillus spp. (Mateo \& Jimenez, 2000; Maices \& Mateo, 2005). The composition of these preparations varies and they are actually a mixture of non-specific glucanases. Consequently, research has also focused on seeking $\beta$-glycosidase enzymes from yeast present in wine ecosystems that might enhance typical wine aromas. The several $\beta$-glucosidases obtained from Saccharomyces or nonSaccharomyces yeasts have been studied as a future application in winemaking (Fernández et al., 2000; Hernández et al., 2002).

Grapes have an enzyme with $\beta$-glycosidase activity, but only low activities have been detected for $\alpha$-rhamnosidase, $\alpha$-arabinosidase, $\beta$-apiosidase and $\beta$-xylosidase. Also, it has been observed that $\beta$-glycosidase has low stability and activity at the $\mathrm{pH}$ values of grape juice and wine, and the activity of $\beta$-glycosidase from Saccharomyces cerevisiae yeast is inhibited by glucose and ethanol (Hernández et al., 2002; Swiegers et al., 2005). For the aforementioned reason, therefore, the most suitable enzymatic preparations for use in winemaking are those having all necessary types of activity (Salinas et al., 2003).

\footnotetext{
*Corresponding author: e-mail: denis.rusjan@bf.uni-lj.si [Tel.: +38-614-231161; Fax: +38-614-231088]

Acknowledgements: We gratefully acknowledge the Wine House Steyer (http://www:freetime.si/02/vino/9253_apace/steyer/steyer.htm) of Slovenia for the donation of grapes. We are also indebted to Prof. Dr Zora Korošec-Koruza and the staff of the Faculty of Chemistry and Chemical Technology for assistance, as well as for financial support.
} 
Pectolytic enzymes have been shown to be suitable for the same purpose because of the side activities of various glucosidases. A number of publications on pectic enzyme treatment have shown that pressing of the grapes and clarification of the musts may increase extraction of substances that contribute to colour (Muñoz et al., 2004) and aroma. However, only the organoleptic quality of wine has been compared (Fernández et al., 2000).

The present study was conducted to investigate the efficacy of treatments with several pectolytic enzyme preparations and with $\beta$-glycosidase available in the market on the terpene release and sensory profile of wines. The selected grapevine variety was Gewürztraminer, which is characterised by a special aroma, in which the terpenols are the most important aromatic compounds. Some of the terpenes are the most odoriferous, especially linalool, $\alpha$-terpineol, nerol, geraniol and citronellol, which have a floral aroma (Reynolds et al., 1996; Ong \& Acree, 1999; Girard et al., 2002; Martin \& Bohlmann, 2004). Terpene release and its quantification were studied using gas chromatography and sensory analysis.

\section{MATERIALS AND METHODS}

\section{Materials}

The grapes of the aromatic Gewürztraminer variety (Vitis vinifera L., clone FR 46-106) were produced in Podravje, in the continental part of Slovenia, by Wine House Steyer. The aromatic variety was chosen because of its high aroma potential for the accurate observation of the eventual impact of the used enzymes on the release of primary aroma compounds.

\section{Sample preparation}

About $280 \mathrm{~kg}$ of grapes were harvested manually at optimal ripeness, crushed and randomly decanted into 24 vessels of 10 L. The musts were analysed for carbohydrate and organic acid content (Šturm et al., 1999), and $\mathrm{pH}$ values were also recorded with a pH meter (InoLab 720 WTW). The chemophysiological characteristics of the must are presented in Table 1 . The must was also treated with sulphur ( $50 \mathrm{mg} \mathrm{K} \mathrm{S}_{2} \mathrm{O}_{5}$ per L of must with skins) to prevent

After decantation, the enzyme preparations listed in Table 2 were added to the vessels; the same preparation was added to three different vessels (which means three replications for each preparation). The quantities of enzyme preparation added followed the instructions of the manufacturers, which are also indicated in the last column in Table 2. The musts treated with pectolytic enzymes were left overnight $(8 \mathrm{~h})$ at $17^{\circ} \mathrm{C}$ and mixed several times before inoculation with Saccharomyces cerevisiae Uvaferm 43, Lallemand ( 0.25 g per litre must). During fermentation the musts were sampled on 2007-10-16 and 2007-
10-20, and after fermentation on 2007-11-02 and 2007-12-07, respectively. Samples $(10 \mathrm{~mL}$, in triplicate) were measured into $20 \mathrm{~mL}$ glass vials, crimped and frozen $\left(-20^{\circ} \mathrm{C}\right)$ until analysis. After fermentation the wines were stabilised, bottled and stored at $15^{\circ} \mathrm{C}$ until analysis.

\section{Chemicals and instrumentation}

Standard samples of glucose, fructose, malic acid and tartaric acid were obtained from Sigma Aldrich (Steinheim, Germany). The selection of the aroma compounds was arbitrary according to monoterpenes mainly known in Gewürztraminer wines (Martin \& Bohlmann, 2004). Standard compounds used in this study were the monoterpenes a-terpineol (99\% purity), nerol ( $90 \%$ purity), geraniol (96\% purity) and linalool (97\% purity), all from Fluka (Buchs, Switzerland). Stock standard solutions of the compounds were prepared by dissolving the weighed solid standard in methanol to obtain a concentration of 0.8 to $1.2 \mathrm{~g} / \mathrm{L}$. These solutions were kept in the refrigerator and were stable for several months.

The solvents $n$-hexane and methanol were of HPLC-grade purity, obtained from Sigma-Aldrich (Steinheim, Germany). Other chemicals used were of p.a. grade and came from different manufacturers. For the solid-phase microextraction, a manual holder, divinylbenzene-carboxen-polydimethylsiloxane (DVB/ CAR/PDMS) and 50/30 mm fibre from Supelco (Bellefonte, PA, USA) were used. For the gas chromatography, helium (>99.999\%) from Messer (Gumpoldskirchen, Austria) was used. The analytical capillary column was VOCOL, with dimensions of $60 \mathrm{~m} \times 0.25 \mathrm{~mm}$ (i.d.), and a film thickness of $1.5 \mathrm{~mm}$ (from Supelco, Bellefonte, PA, USA). The gas chromatograph was an HP 5890 series with a mass spectrometric detector (MSD) 6890 from Hewlett-Packard (Palo Alto, CA, USA).

\section{Analysis of carbohydrates and organic acids}

The samples were prepared according to the method already described (Šturm et al., 1999), with slight modifications. The samples of $1 \mathrm{~mL}$ of must were diluted with bi-distilled water (must : bd water $=1: 10(v / v)$ ). The mixtures were centrifuged for $7 \mathrm{~min}$ at $4200 \mathrm{rpm}$ at room temperature $\left(21^{\circ} \mathrm{C}\right)$. The supernatant was used and filtered through a $0.45 \mu \mathrm{m}$ syringe filter (Chromafil A-25/25, Mecherey-Nagel) prior to injection into the HPLC.

The samples were analysed on the Thermoseparation Product TSP HPLC system, with the diode array detector set at $210 \mathrm{~nm}$ for organic acids and the RI detector set for carbohydrates. The Phenomenex (Rezex RCM-Monosaccharid $\mathrm{Ca}^{+}$; 300 x 7.80 $\mathrm{mm}$ ) and Phenomenex (Rezex ROA-Organic acid $\mathrm{H}^{+} ; 300 \times 7.8$ $\mathrm{mm}$ ) columns were operated at $65^{\circ} \mathrm{C}$. The elution A solvent was aqueous $4 \mathrm{mM} \mathrm{H}_{2} \mathrm{SO}_{4}$ for organic acid and bi-distilled water for

\section{TABLE 1}

The average values (mean \pm standard error; $\mu \mathrm{g} / \mathrm{L}$ ) of the main quality parameters of must from Gewürztraminer produced in Slovenia from the 2007 vintage, before fermentation.

\begin{tabular}{|c|c|c|c|c|c|c|c|}
\hline \multirow{2}{*}{ Variety and clone } & \multicolumn{3}{|c|}{ Sugar content $(\mathrm{g} / \mathrm{L})$} & \multicolumn{3}{|c|}{ Organic acids $(\mathrm{g} / \mathrm{L})$} & \multirow{2}{*}{$\mathrm{pH}$} \\
\hline & Glucose & Fructose & Total & Tartaric & Malic & Total & \\
\hline $\begin{array}{l}\text { Gewürztraminer } \\
\text { (FR 46-106) }\end{array}$ & $107 \pm 10$ & $89 \pm 11$ & $204 \pm 21$ & $3.5 \pm 0.1$ & $2.3 \pm 0.1$ & $6.3 \pm 0.2$ & $3.34 \pm 0.03$ \\
\hline
\end{tabular}


TABLE 2

The name, description and use of selected enzyme preparations added to the musts of Gewürztraminer before fermentation.

\begin{tabular}{|c|c|c|c|c|}
\hline Enzyme preparation & Abbreviation & Producer & Description & Added quantity* \\
\hline Lallzyme BETA & Lall & $\begin{array}{l}\text { Lallemand } \\
\text { (St. Simon, France) }\end{array}$ & $\begin{array}{l}\text { Granulated and formulated for use in white wine varieties high in } \\
\text { 'bound' terpenols, such as Gewürztraminer and Muscat. BETA is a } \\
\text { blend of pectinases with } \beta \text {-glucosidase, rhamnosidase, apiosidase } \\
\text { and arabinofuranosidase. }\end{array}$ & $\begin{array}{l}5 \mathrm{~g} / 100 \mathrm{~L} \\
\text { in solution }\end{array}$ \\
\hline Rohavin VR-C & VRX & $\begin{array}{l}\text { AB Enzymes } \\
\text { (Darmstadt, Germany) }\end{array}$ & $\begin{array}{l}\text { Granulated; this pectinase combined with hemicellulase and } \\
\text { protease is particularly suitable for making red wine. The effect } \\
\text { of the combined enzymes improves the clarification and filtration } \\
\text { of red wines. Pectolytic enzyme (from Aspergillus) with high } \\
\text { proteolytic and hemicellulolytic side activities. }\end{array}$ & $\begin{array}{l}5 \mathrm{~g} / 100 \mathrm{~L} \\
\text { in solution }\end{array}$ \\
\hline Rohapect VR-C & VRC & $\begin{array}{l}\text { AB Enzymes } \\
\text { (Darmstadt, Germany) }\end{array}$ & $\begin{array}{l}\text { Granulated; pectolytic enzyme (from Aspergillus). This pectinase } \\
\text { combined with hemicellulase and protease is particularly suitable } \\
\text { for making red wine. The effect of the combined enzymes improves } \\
\text { the colour extraction and stability, as well as the clarification and } \\
\text { filtration, of red wines }\end{array}$ & $\begin{array}{l}5 \mathrm{~g} / 100 \mathrm{~L} \\
\text { in solution }\end{array}$ \\
\hline Rohavin MX & MX & $\begin{array}{l}\text { AB Enzymes } \\
\text { (Darmstadt, Germany) }\end{array}$ & $\begin{array}{l}\text { Liquid; highly purified pectolytic enzyme (from Aspergillus) for } \\
\text { the treatment of crushed grapes, supports the extraction of varietal } \\
\text { bouquet compounds. Especially suitable for the skin maceration } \\
\text { of white grapes or for making rosé wine. The highly specific } \\
\text { pectinases primarily break down the soluble pectin and thus } \\
\text { improve preliminary juice extraction. }\end{array}$ & $\begin{array}{l}5 \mathrm{~mL} / 100 \mathrm{~L} \\
\text { in solution }\end{array}$ \\
\hline Rohapect D5L & D5L & $\begin{array}{l}\text { AB Enzymes } \\
\text { (Darmstadt, Germany) }\end{array}$ & $\begin{array}{l}\text { Liquid; pectolytic enzyme (from Aspergillus), universal application } \\
\text { in juice processing. }\end{array}$ & $\begin{array}{l}5 \mathrm{~mL} / 100 \mathrm{~L} \\
\text { in solution }\end{array}$ \\
\hline Endozym - Cultivar A & Cult. A & $\begin{array}{l}\text { Pascal Biotech } \\
\text { (Pôle Industriel, } \\
\text { Île de France, France) }\end{array}$ & $\begin{array}{l}\text { Microgranulated; pectolytic enzyme based on pectinase to obtain } \\
\text { characteristic varietals during the treatment and grape. It makes } \\
\text { available in the volatile form, since the aromatic compounds } \\
\text { present at the end of the fermentation are combined in molecules } \\
\text { with sugars in the form of terpenic bi-glycosides. }\end{array}$ & $\begin{array}{l}5 \mathrm{~g} / 100 \mathrm{~L} \\
\text { in solution }\end{array}$ \\
\hline Glucosidase $(\beta)$ & Glucosidase & $\begin{array}{l}\text { Fluka } \\
\text { (Buchs, Switzerland) }\end{array}$ & Microgranulated; from Aspergillus niger & $\begin{array}{l}0.25 \mathrm{~g} / 100 \mathrm{~L} \\
\text { directly }\end{array}$ \\
\hline
\end{tabular}

* The added quantity of enzyme preparations was prepared according to the manufacturers' instructions.

carbohydrates. Samples of $20 \mu \mathrm{L}$ were injected at a flow rate of 0.6 $\mathrm{mL} / \mathrm{min}$. The carbohydrate and organic acid concentrations were calculated with the help of corresponding external standards. The concentrations were expressed as $\mathrm{g} / \mathrm{L}$ fresh weight (FW).

\section{Extraction and analysis of volatile compounds}

Fresh and fermentation must were left in a vial to defrost at room temperature and then subjected to HS-SPME-GC-MS analysis. Extraction of aroma compounds were according to the method of Prosen et al. (2007).

In the mass spectrometer, electron impact (EI) ionisation was used and the chromatograms were recorded in the total ion current (TIC) mode. Compounds were identified on the basis of their retention times (comparison with standards) and spectra using the searchable EI-MS spectra library (NIST02). The peak area for quantitation was measured either in the TIC chromatogram or in an extracted ion chromatogram in the case of co-elution with other compounds.

\section{Sensory evaluation of wines}

Wines tasting was conducted in two one-hour sessions, separated by a 30 min break. The environment (uniform lighting, ambient temperature between 19 and $22^{\circ} \mathrm{C}$, silence, etc.) of the sensory facility room was equipped as advised for sensory laboratories at the International Wine Competition (OIV, 1994). Five professionals participated at any one time. Prior to tasting, each taster was provided with information about the study and with the instructions to be implemented when filling in the wine sensory evaluation. The participants were then seated at separate desks, where eight wine samples were placed in the order designated for the particular participant. Wines were sampled $(50 \mathrm{~mL})$ at ambient temperature, served in standard, coded wine-tasting glasses (ISO, 1977). The participants first undertook three ortho-nasal evaluations for each wine samples and signed the appropriate number alongside intensity. The descriptors assigned were: litchi, rose, flowers, honey and lemon (Reynolds et al., 
TABLE 3

The olfactory descriptions and average contents of the determined monoterpenes (mean \pm standard error; $\mu \mathrm{g} / \mathrm{L}$ ) in our study and in already published data on Gewürztraminer wines.

\begin{tabular}{|c|c|c|c|c|}
\hline Monoterpene & Olfactory description (aroma) & $\begin{array}{c}\text { Average } \\
(\mu \mathrm{g} / \mathrm{L})\end{array}$ & $\begin{array}{l}\text { R.G. }^{(1)} \\
(\mu \mathrm{g} / \mathrm{L})\end{array}$ & $\begin{array}{c}P^{(2)} \\
(\mu \mathrm{g} / \mathrm{L})\end{array}$ \\
\hline Geraniol & Rose & $17.1 \pm 0.5$ & 218.0 & n.d. \\
\hline Nerol & Rose & $21.3 \pm 0.8$ & 43.0 & 18.9 \\
\hline$\alpha$-Terpineol & Lily & $4.9 \pm 0.1$ & 3.0 & 15.9 \\
\hline Linalool & Rose & $4.7 \pm 0.2$ & 6.0 & 13.3 \\
\hline
\end{tabular}

n.d. $=$ not detected

(1) Ribéreau-Gayon et al. (2000)

(2) Piñeiro et al. (2006)

\section{TABLE 4}

Average content of geraniol (mean \pm standard error; $\mu \mathrm{g} / \mathrm{L}$ ) in musts and wines made with Gewürztraminer grapes from the 2007 vintage, according to the treatments with enzyme preparations and before fermentation. Significant differences between treatments are indicated by different letters at $P<0.05$ (Duncan test) (ANOVA; $\mathrm{n}=3$ ).

\begin{tabular}{lccc}
\hline Enzyme & $\mathbf{2 0 0 7 - 1 0 - 1 6}$ & $\mathbf{2 0 0 7 - 1 0 - 2 0}$ & $\mathbf{2 0 0 7 - 1 1 - 0 2}$ \\
\hline Lall & $46.5 \pm 9.2 \mathrm{a}$ & $495.0 \pm 113.5 \mathrm{~b}$ & $27.7 \pm 5.1 \mathrm{c}$ \\
VRX & $121.0 \pm 36.4 \mathrm{~b}$ & $94.9 \pm 24.3 \mathrm{a}$ & $15.5 \pm 8.4 \mathrm{ab}$ \\
D5L & $152.9 \pm 41.0 \mathrm{~b}$ & $104.2 \pm 19.7 \mathrm{a}$ & $14.5 \pm 2.2 \mathrm{~b}$ \\
MX & $165.1 \pm 49.6 \mathrm{bc}$ & $153.8 \pm 45.2 \mathrm{a}$ & $23.1 \pm 15.2 \mathrm{bc}$ \\
VRC & $175.3 \pm 49.6 \mathrm{bc}$ & $74.1 \pm 10.6 \mathrm{a}$ & $11.2 \pm 2.2 \mathrm{a}$ \\
Cult. A & $174.7 \pm 35.5 \mathrm{bc}$ & $135.8 \pm 14.7 \mathrm{a}$ & $6.3 \pm 4.6 \mathrm{a}$ \\
Glucosidase & $236.0 \pm 38.4 \mathrm{c}$ & $117.5 \pm 15.3 \mathrm{a}$ & $12.6 \pm 2.0 \mathrm{a}$ \\
Control & $198.1 \pm 97.5 \mathrm{bc}$ & $141.2 \pm 66.0 \mathrm{a}$ & $14.5 \pm 4.7 \mathrm{ab}$ \\
\hline
\end{tabular}

Lall = Lallzyme- $\beta ;$ VRX = Rohavin VR-C ; D5L = Rohapect D5L; MX = Rohavin MX; VRC $=$ Rohapect VRC ; Cult. A = Endozym cultivar A

\section{TABLE 5}

Average content of $\alpha$-terpineol (mean \pm standard error; $\mu \mathrm{g} / \mathrm{L}$ ) in musts and wines made with Gewürztraminer grapes from the 2007 vintage, according to the treatments with enzyme preparations and before fermentation. Significant differences between treatments are indicated by different letters at $P<0.05$ (Duncan test) (ANOVA; $\mathrm{n}=3$ ).

\begin{tabular}{lccc}
\hline Enzyme & $\mathbf{2 0 0 7 - 1 0 - 1 6}$ & $\mathbf{2 0 0 7 - 1 0 - 2 0}$ & $\mathbf{2 0 0 7 - 1 1 - 0 2}$ \\
\hline Lall & $0.8 \pm 0.2 \mathrm{a}$ & $14.9 \pm 1.1 \mathrm{~d}$ & $9.4 \pm 0.8 \mathrm{~b}$ \\
VRX & $0.9 \pm 0.5 \mathrm{~b}$ & $3.6 \pm 0.6 \mathrm{~b}$ & $4.7 \pm 1.5 \mathrm{a}$ \\
D5L & $0.9 \pm 0.2 \mathrm{~b}$ & $2.4 \pm 1.4 \mathrm{ab}$ & $3.7 \pm 0.7 \mathrm{a}$ \\
MX & $1.0 \pm 0.3 \mathrm{~b}$ & $7.4 \pm 1.6 \mathrm{c}$ & $4.0 \mathrm{~b}$ \\
VRC & $1.0 \pm 0.3 \mathrm{~b}$ & $2.1 \pm 1.0 \mathrm{a}$ & $4.9 \pm 0.4 \mathrm{a}$ \\
Cult. A & $0.9 \pm 0.2 \mathrm{~b}$ & $2.8 \pm 0.4 \mathrm{ab}$ & $4.5 \pm 0.8 \mathrm{a}$ \\
Glucosidase & $1.0 \pm 0.3 \mathrm{~b}$ & $2.2 \pm 1.1 \mathrm{a}$ & $4.0 \pm 1.8 \mathrm{a}$ \\
Control & $1.0 \pm 0.5 \mathrm{~b}$ & $4.7 \pm 0.4 \mathrm{a}$ & $4.1 \pm 1.5 \mathrm{a}$ \\
\hline
\end{tabular}

Lall = Lallzyme- $\beta$; VRX = Rohavin VR-C ; D5L = Rohapect D5L; MX = Rohavin MX; VRC = Rohapect VRC ; Cult. A = Endozym cultivar A 


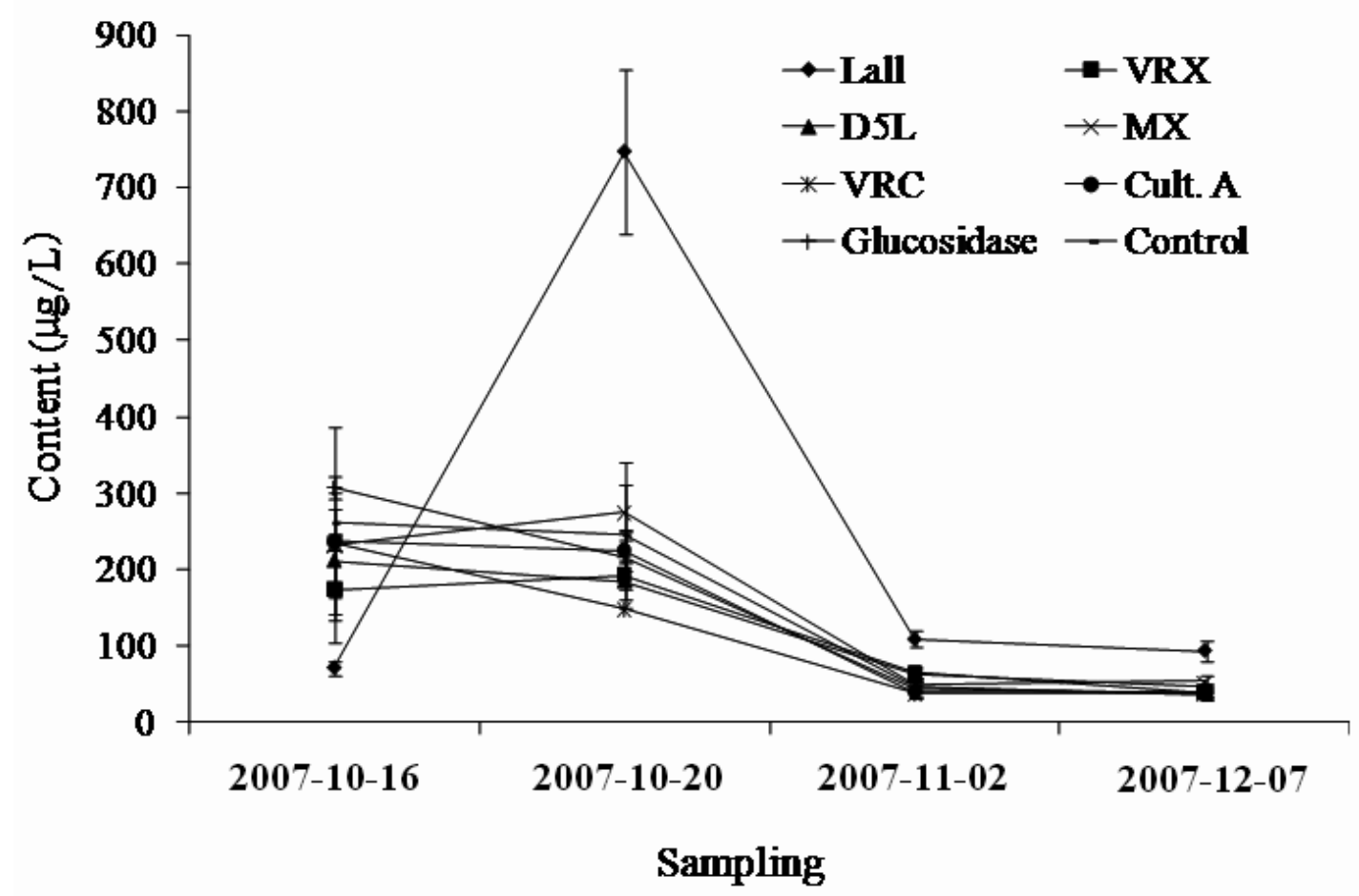

FIGURE 1

The average content of total monoterpene compounds (TMT; $\mu \mathrm{g} / \mathrm{L}$ ) in musts and wines from Gewürztraminer during vinification, according to enzyme treatments. The standard error bars are given at each data point. The must and wine treated with the Lall enzyme preparation showed statistically significant differences in TMT contents at $p<0.001$, based on the Duncan test.

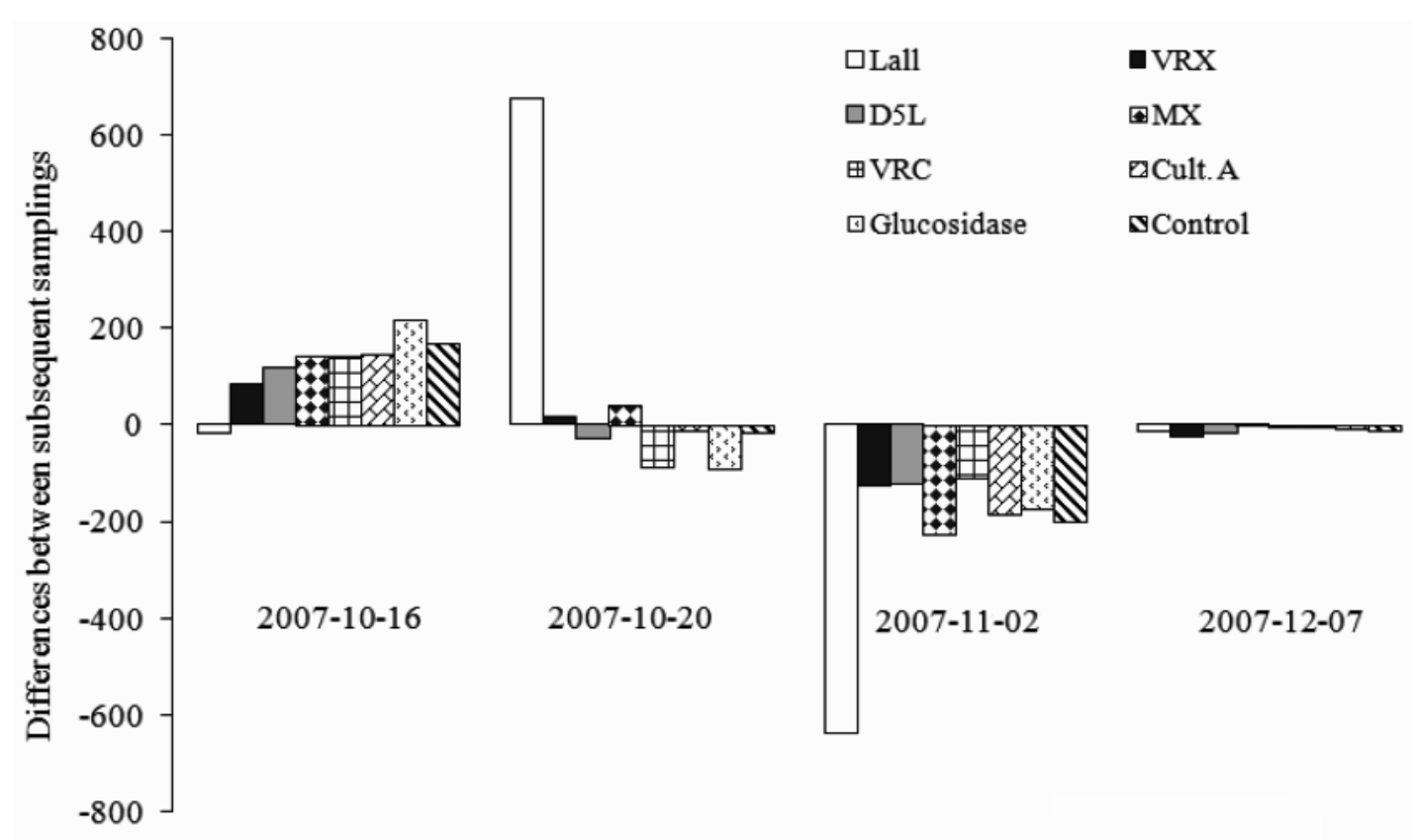

Sampling: 
1996; Ong \& Acree, 1999). The tasters were requested to rate the intensity of the aroma and the retro-nasal aroma, as well as the tactile descriptor, harmony, impression and pleasure. A $10 \mathrm{~mm}$ unstructured-line score sheet, anchored at and quantified between 0 and 10 , was used (from $0=$ poor to $10=$ exceptional).

\section{Statistical analysis}

All the data obtained were analysed by Statgraphic 4.00 software using one-way ANOVA. The differences were evaluated using Duncan's test at $p \leq 0.05,0.01$ and 0.001 , in other words what is considered to be statistically different. Means and standard errors are presented. The sensory data was additionally analysed by principal components analysis (PCA) on the correlation matrices of the raw sensory score.

\section{RESULTS AND DISCUSSION}

\section{Aroma compounds in grapes}

The grapes of Gewürztraminer contained geraniol $(66.7 \mu \mathrm{g} / \mathrm{L})$ as the most abundant monoterpene, followed by nerol (13.3 $\mu \mathrm{g} / \mathrm{L}), \alpha$-terpineol $(7.8 \mu \mathrm{g} / \mathrm{L})$ and finally linalool $(3.3 \mu \mathrm{g} / \mathrm{L})$. The contents of single monoterpenes obtained varied greatly, as found in previous studies (Wilson et al., 1986; Girard et al., 2002).

\section{Aroma compounds in musts and wines}

At the first sampling of semi-fermented must (2007-10-16), the average total monoterpene (TMT) concentration increased by $125.3 \mu \mathrm{g} / \mathrm{L}$ compared to musts before fermentation (Fig. 1). The exception was the must treated with Lall enzyme, in which the TMT decreased by $18.8 \mu \mathrm{g} / \mathrm{L}$ (Figs 1 and 2). The highest increase was observed in must treated with $\beta$-glucosidase, especially for geraniol $(169.3 \mu \mathrm{g} / \mathrm{L})$ and nerol $(51.5 \mu \mathrm{g} / \mathrm{L})$, where the average TMT reached $236.0 \mu \mathrm{g} / \mathrm{L}$ (Tables 4 and 6; Fig. 2). The biggest statistically significant differences in geraniol contents were observed between Lall and glucosidase, where approximately five times more was found in contents were determined, respectively. The differences in nerol contents among the enzyme preparations were not so significant (Table 4).

Over the next four days (until 2007-10-20), the average TMT increased further only in the semi-fermented musts treated with enzymes VRX, MX and especially for Lall, where an increase of $675.5 \mu \mathrm{g} / \mathrm{L}$ was observed. The biggest statistically significant differences in the content of single terpenes were shown between Lall and all the other treatments. At that time, the wine had 747.7 $\mu \mathrm{g} / \mathrm{L}$ TMT, dispensed as $495.0 \mu \mathrm{g} / \mathrm{L}$ of geraniol, $225.5 \mu \mathrm{g} / \mathrm{L}$ of nerol, $14.9 \mu \mathrm{g} / \mathrm{L}$ of $\alpha$-terpineol and $12.3 \mu \mathrm{g} / \mathrm{L}$ of linalool (Figs 1 and 2; Tables 4 to 7 ).

In the period to the end of the fermentation, the TMT concentrations in all the treatments decreased drastically, with approximately $222.7 \mu \mathrm{g} / \mathrm{L}$ compared to the previous sampling. The average TMT concentration in the young wine was 56.7 $\mu \mathrm{g} / \mathrm{L}$, where nerol $(32.6 \mu \mathrm{g} / \mathrm{L})$ and geraniol $(14.7 \mu \mathrm{g} / \mathrm{L})$ were predominant (Tables 4, 5 and 6). The highest concentrations of geraniol $(27.7 \mu \mathrm{g} / \mathrm{L}), \operatorname{nerol}(66.3 \mu \mathrm{g} / \mathrm{L}), \alpha$-terpineol $(9.4 \mu \mathrm{g} / \mathrm{L})$ and linalool $(6.1 \mu \mathrm{g} / \mathrm{L})$ were determined in wine from must treated with the Lall enzyme, followed by wine treated with VRX enzyme (Fig. 1; Tables 4 to 7). Young wines made with musts treated with the enzymes VRC and Cult. A and also with $\beta$-glucosidase had lower average TMT concentrations compared to the control.

The concentration of aroma compounds in the Gewürztraminer wine was determined again after one month in bottles. In that time there were also statistically significant differences in the single terpene content between wines treated with Lall and those

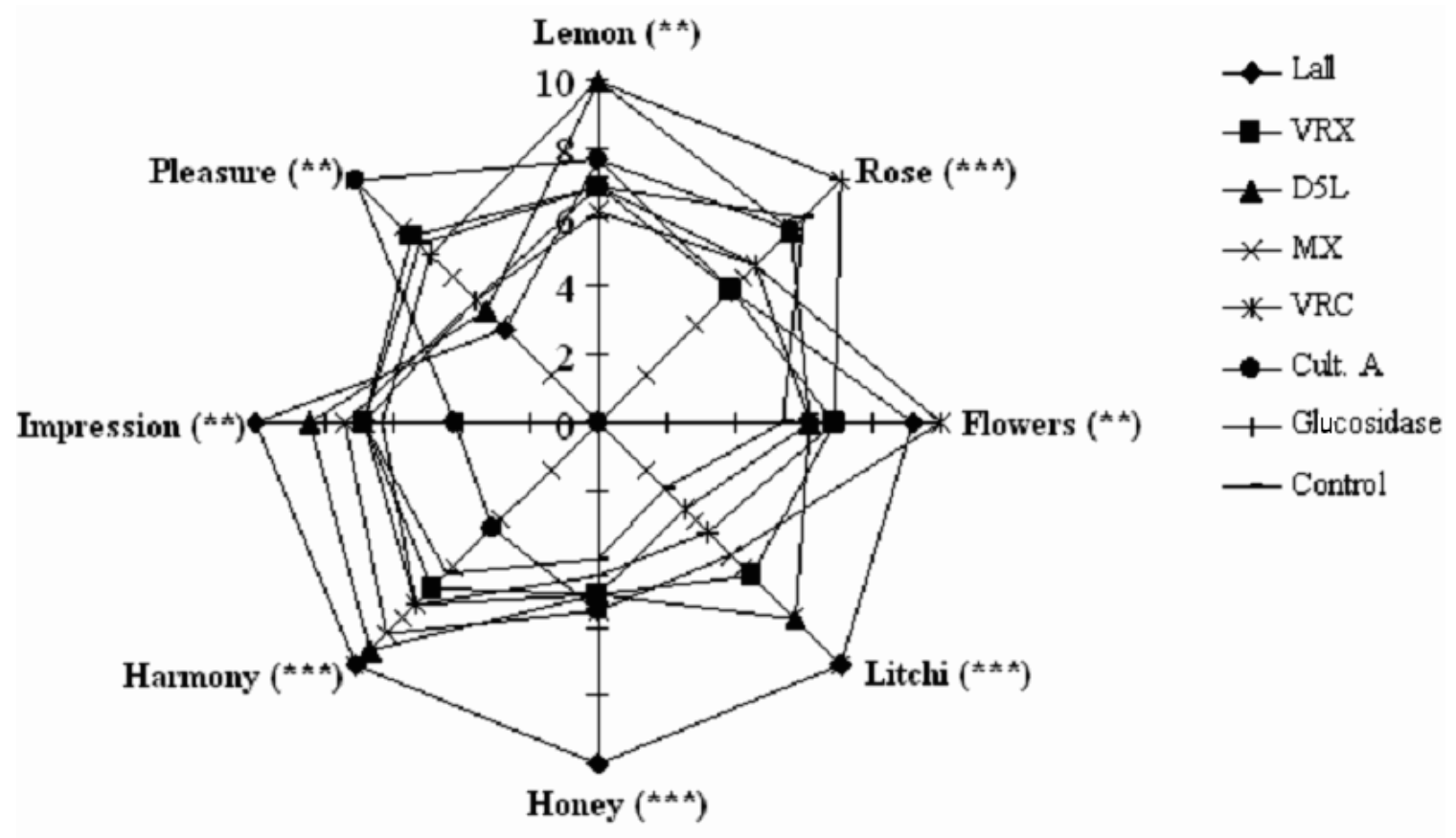

FIGURE 3

Mean sensory profile of the descriptive analysis of Gewürztraminer wines according to enzyme treatments. Legend: *,*,***: significant at $p \leq 0.05,0.01,0.001$ respectively. 
TABLE 6

Average content of nerol (mean \pm standard error; $\mu \mathrm{g} / \mathrm{L}$ ) in musts and wines made with Gewürztraminer grapes from the 2007 vintage, according to the treatments with enzyme preparations and before fermentation. Significant differences between treatments are indicated by different letters at $P<0.05$ (Duncan test) (ANOVA; $\mathrm{n}=3$ ).

\begin{tabular}{|c|c|c|c|c|}
\hline Enzyme & $2007-10-16$ & 2007-10-20 & 2007-11-02 & 2007-12-07 \\
\hline Lall & $21.8 \pm 2.7 \mathrm{a}$ & $225.5 \pm 37.7 b$ & $66.3 \pm 2.6 \mathrm{c}$ & $45.9 \pm 5.0 \mathrm{~b}$ \\
\hline VRX & $47.1 \pm 14.9 \mathrm{~b}$ & $88.3 \pm 49.7 \mathrm{a}$ & $40.1 \pm 11.8 b$ & $16.3 \pm 1.2 \mathrm{a}$ \\
\hline D5L & $52.9 \pm 10.2 \mathrm{~b}$ & $71.9 \pm 36.1 \mathrm{a}$ & $29.6 \pm 4.5 \mathrm{a}$ & $21.1 \pm 6.9 \mathrm{a}$ \\
\hline MX & $60.8 \pm 11.0 \mathrm{~b}$ & $106.1 \pm 22.2 \mathrm{a}$ & $28.3 \pm 7.2 \mathrm{a}$ & $22.1 \pm 4.6 \mathrm{a}$ \\
\hline VRC & $52.4 \pm 29.1 \mathrm{~b}$ & $65.0 \pm 15.6 \mathrm{a}$ & $24.0 \pm 3.2 \mathrm{a}$ & $16.5 \pm 1.6 \mathrm{a}$ \\
\hline Cult. A & $56.8 \pm 4.7 \mathrm{~b}$ & $80.1 \pm 8.5 \mathrm{a}$ & $23.5 \pm 6.7 \mathrm{a}$ & $17.6 \pm 2.6 \mathrm{a}$ \\
\hline Glucosidase & $64.8 \pm 10.1 \mathrm{~b}$ & $90.3 \pm 16.3 \mathrm{a}$ & $21.3 \pm 3.2 \mathrm{a}$ & $15.3 \pm 5.6 \mathrm{a}$ \\
\hline Control & $56.9 \pm 24.3 \mathrm{~b}$ & $94.6 \pm 35.6 \mathrm{a}$ & $27.8 \pm 9.7 \mathrm{a}$ & $15.3 \pm 2.9 \mathrm{a}$ \\
\hline
\end{tabular}

Lall = Lallzyme- $\beta ; \mathrm{VRX}=$ Rohavin VR-C $;$ D5L = Rohapect D5L; MX = Rohavin MX; VRC = Rohapect VRC ; Cult. A = Endozym cultivar A

\section{TABLE 7}

Average content of linalool (mean \pm standard error; $\mu \mathrm{g} / \mathrm{L}$ ) in musts and wines made with Gewürztraminer grapes from the 2007 vintage, according to the treatments with enzyme preparations and before fermentation. Significant differences between treatments are indicated by different letters at $P<0.05$ (Duncan test) (ANOVA; n $=3$ ).

\begin{tabular}{|c|c|c|c|c|}
\hline $\begin{array}{ll} & \text { Sampling } \\
\text { Enzyme } & \\
\end{array}$ & 2007-10-16 & 2007-10-20 & 2007-11-02 & 2007-12-07 \\
\hline Lall & $3.2 \pm 0.4 \mathrm{a}$ & $12.3 \pm 1.8 \mathrm{c}$ & $6.1 \pm 0.6 \mathrm{~d}$ & $6.4 \pm 0.9 \mathrm{c}$ \\
\hline VRX & $5.0 \pm 2.0 \mathrm{~b}$ & $5.9 \pm 0.6 \mathrm{a}$ & $4.5 \pm 0.5 b c$ & $4.4 \pm 1.0 \mathrm{ab}$ \\
\hline D5L & $4.7 \pm 1.5 \mathrm{~b}$ & $6.2 \pm 0.8 \mathrm{a}$ & $4.9 \pm 0.3 \mathrm{c}$ & $5.0 \pm 0.6 \mathrm{~b}$ \\
\hline $\mathrm{MX}$ & $5.3 \pm 1.6 \mathrm{~b}$ & $8.0 \pm 1.0 \mathrm{~b}$ & $4.2 \pm 0.6 \mathrm{ab}$ & $4.9 \pm 0.7 \mathrm{ab}$ \\
\hline VRC & $5.9 \pm 1.7 \mathrm{~b}$ & $6.5 \pm 1.4 \mathrm{ab}$ & $3.9 \pm 0.5 \mathrm{a}$ & $4.3 \pm 0.7 \mathrm{ab}$ \\
\hline Cult. A & $4.8 \pm 0.2 \mathrm{~b}$ & $6.4 \pm 0.7 \mathrm{ab}$ & $3.8 \pm 0.7 \mathrm{a}$ & $4.1 \pm 0.6 \mathrm{a}$ \\
\hline Glucosidase & $6.2 \pm 0.3 \mathrm{~b}$ & $6.7 \pm 1.1 \mathrm{ab}$ & $4.3 \pm 0.9 \mathrm{ab}$ & $4.2 \pm 0.3 \mathrm{ab}$ \\
\hline Control & $5.1 \pm 2.4 \mathrm{~b}$ & $6.6 \pm 2.6 \mathrm{ab}$ & $4.3 \pm 0.5 \mathrm{ab}$ & $4.2 \pm 0.5 \mathrm{ab}$ \\
\hline
\end{tabular}

Lall = Lallzyme- $\beta ;$ VRX $=$ Rohavin VR-C ; D5L = Rohapect D5L; MX = Rohavin MX; VRC = Rohapect VRC ; Cult. A = Endozym cultivar A

with all the other treatments (Tables 4 to 7). The average TMT concentration compared to the previous sampling decreased by $8.8 \mu \mathrm{g} / \mathrm{L}$, excepted for enzyme MX, in which case it increased by $4.2 \mu \mathrm{g} / \mathrm{L}$ (Figs 1 and 2). The average TMT concentration in wines, no matter what treatment, was $47.9 \mu \mathrm{g} / \mathrm{L}$, where the lowest concentration of $37.0 \mu \mathrm{g} / \mathrm{L}$ was determined in the control wines. The most aromatic wine was made using the Lall enzyme, where the highest concentrations of nerol $(45.9 \mu \mathrm{g} / \mathrm{L})$, geraniol $(31.8 \mu \mathrm{g} / \mathrm{L}), \alpha$-terpineol $(10.5 \mu \mathrm{g} / \mathrm{L})$ and linalool $(6.4 \mu \mathrm{g} / \mathrm{L})$ were determined (Tables 4, 5, 6 and 7, Fig. 1). This was also expected because of the claims of its manufacturer (Table 2). The comparison of our data from the analysed monoterpenes content in wines with that already mentioned and citied in previous articles is showed in Table 3 (Ribéreau-Gayon et al., 2000; Piñeiro et al., 2006). Fernández-Zurbano et al. (1999), Ganga et al. (2001), Tamborra et al. (2004) and Genovés et al. (2005) showed that all wines from musts treated with enzymes had higher average TMT concentrations compared to the control, and this was also confirmed in our research (Fig. 1). However, slightly higher concentrations were seen in wines from musts treated with VRX, VRC, Cult A. and glucosidase (Fig. 1). According to the specifications of enzyme manufacturers, the results for enzymes VRX and VRC were expected because they are recommended for red musts (Table 2). Unexpectedly low aroma compounds were determined for enzyme Cult. A and glucosidase, although they should have increased the aroma potential of wines according to their manufacturers (Table 3). The differences in the content of monoterpene compounds in the grape and wines, but also in the grape, could be explained by impacts of different terroir characteristics (Smart \& Robinson, 1991; Reynolds et al., 1996; Miklósy \& Kerény, 2004), winemaking processes (Spillman et al., 2004; Francis \& Newton, 2005; Swiegers et al., 2005; Piñeiro et al., 2006; Comuzzo et al., 2006; Chalier et al., 2007), different extraction and analysis methods (Ortega-Heras et al., 2002), and also by less appropriate physiochemical characteristics of the musts (Barbagallo et al., 2004).

\section{Sensory descriptive analysis}

A descriptive analysis of the Gewürztraminer wine is given in Fig. 3. From the results of the chemical analysis of the wine, the data from the sensory tasting were expected to show higher scores for the wine made with Lall enzyme, in which a nasal odour of litchi, 
honey and flowers predominated. This wine was also the most harmonious and impressive, but unexpectedly less pleasant (Fig. $3)$. The second most aromatic wine was evaluated as the wine made with $\beta$-glucosidase, where lemon and rose odours prevailed. This wine was more harmonious, but it got lower scores for impression and pleasure. The most pleasant wine was that made with enzyme Cult. A, where the medium flavour of several odours was tasted, although it received worse scores for harmony and impression. In the control wine the flavour of rose predominated, followed by lemon and floral aromas. Although the concentration of aroma compounds, especially monoterpenes, was higher in the wines treated with enzymes compared to the control wine, in several cases the flavour of the tasted wines did not follow the results of the chemical analysis. The results showed the impacts of enzymes on an increase in aroma compounds that cause litchi, honey and floral aromas, but in many cases also lemon flavour, and less so rose flavour (Fig. 3).

\section{CONCLUSIONS}

The results of the chemical analysis suggest that Gewürztraminer wine made with Lall enzyme should receive high scores in the sensory or organoleptic tasting. Accordingly, an odour of litchi, honey and flowers was expected. Although the concentrations of monoterpenic compounds were higher in the wines treated with enzymes compared to the control wine, and lower than the olfactory perception threshold (Table 3) (Ribéreau-Gayon et al., 2000), the flavour of the tasted wines could not be strongly linked to the results of the chemical analysis. The reason could be that the combinations of the different contents of primary aroma compounds in the wines caused diverse organoleptic sensations and perceptions.

\section{LITERATURE CITED}

Barbagallo, R.N., Spagna, G., Palmeri, R., Restuccia, C. \& Giudici, P., 2004. Selection, characterization and comparison of beta-glucosidase from mould and yeasts employable for enological applications. Enzyme Microb. Technol. 35, 5866.

Bayonove, C., 1993. Les composes terpeniques. In: Doneche, B. (ed). Les acquisitions récentes en chromatographie du vin. Applications á l'analyse sensorielle des vins. Lavoisier, Paris. pp. 99 - 119.

Bureau, S.M., Baumes, R.L. \& Razungles, A.J., 2000. Effects of vine or bunch shading on the glycosylated flavour precursors in grapes of Vitis vinifera L. cv. Syrah. J. Agric. Food. Chem. 48, 1290-1297.

Cabaroglu, T., Selli, S., Canbas, A., Leproutre, J.P. \& Günata, Z., 2003. Wine flavour enhancement through the use of exogenous fungal glycosidases. Enzyme Microb. Technol. 33, 581-586.

Chalier, P., Angot, B., Delteil, D., Doco, T. \& Günata, Z., 2007. Interactions between aroma compounds and whole mannoprotein isolated from Saccharomyces cerevisiae strains. Food Chem. 100, 22-30.

Comuzzo, P., Tat, L., Tonizzo, A. \& Battistutta, F., 2006. Yeast derivates (extracts and autolysates) in winemaking: release of volatile compounds and effects on wine aroma volatility. Food Chem. 99, 217-230.

Darriet, P., Bouchilloux, P., Poupot, C., Bugaret, Y., Clerjeau, M., Sauris, P., Medina, B. \& Dubourdieu, D., 2001. Effects of copper fungicide spraying on volatile thiols of the varietal aroma of Sauvignon blanc, Cabernet Sauvignon and Merlot wines. Vitis 40, 93-99.

Estévez, P., Gil, M.A. \& Falqué, E., 2004. Effects of seven yeast strains on the volatile composition of Palomino wines. Int. J. Food Sci. Technol. 39, 61-69.

Fernández, M., Úbeda, J.F. \& Briones, A.I., 2000. Typing of non-Saccharomyces yeasts with enzymatic activities of interest in wine-making. Int. J. Food Microbiol. 59, 29-36.
Fernández-Zurbano, P., Ferreira, V., Peña, C., Escudero, A. \& Cacho, J., 1999. Effects of maceration time and pectolytic enzymes added during maceration on the phenolic composition of must. Food Sci. Technol. Int. 5, 319-325.

Francis, I.L. \& Newton, J.L., 2005. Determining wine aroma from compositional data. Aust. J. Grape Wine Res. 11, 114-126.

Ganga, A., Oiñaga, F., Querol, A., Vallés, S. \& Ramón, D., 2001. Cell-wall degrading enzymes in the release of grape aroma precursors. Food Sci. Technol. Int. 7, 83-87.

Genovés, S., Gil, J.V., Vallés, S., Casas, J.A. \& Manzanares, P., 2005. Assessment of the aromatic potential of Palmino fino grape must using glucosidases. Am. J. Enol. Vitic. 56, 88-191.

Girard, B., Fukumoto, L., Mazza, G., Delaquis, P. \& Ewert, B., 2002. Volatile terpene constituents in maturing Gewurztraminer grapes from British Columbia. Am. J. Enol. Vitic. 53, 99-109.

Günata, Z., Bayonove, C.L., Baumes, R.L. \& Cordonnier, R.E., 1985. The aroma of grape. I. Extraction and determination of free and glycosidically bound fraction of some grape aroma components. J. Chromat. 331, 83-90.

Hernández, L.F., Espinosa, J.C., Fernández-González, M., \& Briones, A., 2002. B-glycosidase activity in a Saccharomyces cerevisiae strain. Int. J. Food Microbiol. 80, 171-176.

ISO, 1977. Sensory analysis - apparatus - wine-tasting glass. Geneva.

Košmerl, T., Jakončič, M., Kralj Cigić, I., Strlič, M., \& Prosen, H., 2008. Aroma compounds in "sur lies" produced and aged Chardonnay wines. In: $31^{\circ}$ Cong. Mond. Vigna e del Vino, June 2008, Verona, Italy. pp. 1 -9.

Lambrechts, M.G. \& Pretorius, I.S., 2000. Yeast and its importance to wine aroma - a review. S. Afr. J. Enol. Vitic. 21, 97-129.

Maicas, S. \& Mateo, J.J., 2005. Hydrolysis of terpenyl glycosides in grape juice and other fruit juices: a review. Appl. Microbiol. Biotechnol. 67, 322-335.

Martin, D.M. \& Bohlmann, J., 2004. Identification of Vitis vinifera (-)- $\alpha$-terpineol synthase by in silico screening of full-length cDNA ESTs and functional characterization of recombinant terpene synthase. Phytochemistry 65, 1223-1229.

Mateo, J.J. \& Jimenez, M., 2000. Monoterpenes in grape juice and wines. J. Chromat. A 881, 557-567.

Miklósy, E. \& Kerény, Z., 2004. Comparison of the volatile aroma components in noble rotted grape berries from two different locations of the Tokaj wine district in Hungary. Anal. Chim. Acta 513, 177-181.

Muñoz, O., Sepúlveda, M. \& Schwartz, M., 2004. Effects of enzymatic treatment on anthocyanic pigments from grapes skin from Chilean wine. Food Chem. 87, 487-490.

O.I.V., 1994. Standard on international wine competition, Office International de la Vigne et du Vin, Paris.

Ong, P.K.C. \& Acree, T.E., 1999. Similarities in the aroma chemistry of Gewürztraminer variety wines and lychee (Litchi chinesis Sonn.) fruit. J. Agric. Food Chem. 47, 665-670.

Ortega-Heras, M., González-SanJosé, M.L. \& Beltrán, S., 2002. Aroma composition of wine studied by different extraction methods. Anal. Chim. Acta 458, 85-93.

Peyrot des Gachons, C., Van Leeuwen, C., Tominaga, T., Soyer, J.P., Gaudillere, J.P. \& Dubourdieu, D., 2005. Influence of water and nitrogen deficit on fruit ripening and aroma potential of Vitis vinifera $\mathrm{L} \mathrm{cv}$. Sauvignon blanc in field conditions. J. Sci. Food and Agric. 85, 73-85.

Piñeiro, Z., Natera, R., Castro, R., Palma, M., Puertas, B. \& Barroso, C.G., 2006. Characterisation of volatile fraction of monovarietal wines: influence of winemaking practices. Anal. Chim. Acta 563, 165-172.

Prosen, H., Janeš, L., Strlič, M., Rusjan, D. \& Kočar, D., 2007. Analysis of free and bound aroma compounds in grape berries using headspace solid-phase microextraction with GC-MS and a preliminary study of solid-phase extraction with LC-MS. Acta Chim. Slov. 54, 25-32.

Reynolds, A.G., Wardle, D.A. \& Dever, M., 1996. Vine performance, fruit composition, and wine sensory attributes of Gewürztraminer in response to vineyard location and canopy manipulation. Am. J. Enol. Vitic. 47, 77-92.

Ribéreau-Gayon, P., Glories, Y., Maujean, A. \& Dubourdieu, D., 2000. Varietal aroma. In: Ribéreau-Gayon, P., Glories, Y., Maujean, A. \& Dubourdieu, D. (eds.). Handbook of enology. The chemistry of wine stabilization and treatments, vol II. Lavoisier, Paris. pp. $187-206$. 
Sala, C., Busto, O., Guasch, J. \& Zamora, F., 2004. Influence of vine training and sunlight exposure on the 3-alkyl-2-methoxypyrazines content in musts and wines from the Vitis vinifera variety Cabernet Sauvignon. J. Agri. Food Chem. $52,3492-3497$.

Salinas, M.R., Garijo, J., Pardo, F., Zalacain, A. \& Alonso, G.L., 2003. Color, polyphenol, and aroma compounds in rose wines after prefermentative maceration and enzymatic treatments. Am. J. Enol. Vitic. 54, 195-199.

Sánchez-Palomo, E., Díaz-Maroto, H.M.C., González-Viñas, M.A. \& PérezCoello, M.S., 2005. Aroma enhancement in wines from different grape varieties using exogenous glucosidases. Food Chem. 92, 627-635.

Smart, R. \& Robinson, M., 1991. Sunlight into wine. Winetitles, Adelaide.

Spillman, P.J., Sefton, M.A. \& Gawel, R., 2004. The contribution of volatile compounds derived during oak barrel maturation to the aroma of a Chardonnay and Cabernet Sauvignon wine. Aust. J. Grape. Wine Res. 10, 227-235.

Swiegers, J.H., Bartowsky, E.J., Henschke, P.A., \& Pretorius, I.S., 2005. Yeast and bacterial modulation of wine aroma and flavour. Aust. J. Grape Wine Res. $11,139-173$.
Šturm, K., Štampar, F. \& Usenik, V., 1999. Evaluating of some quality parameters of different apricot cultivars using HPLC method. Acta Aliment. 4, 297-309.

Swiegers, J.H., Bartowsky, E.J., Henschke, P.A. \& Pretorius, I.S., 2005. Yeast and bacterial modulation of wine aroma and flavour. Aust. J. Grape Wine Res. 11, $139-173$

Tamborra, P., Martino, N. \& Esti, M., 2004. Laboratory tests on glucosidase preparations in wine. Anal. Chim. Acta 513, 299-303.

Valcárcel M.C. \& Palacios, V., 2008. Influence of 'Novarom G' pectinase $\beta$-glycosidase enzyme on the wine aroma of four white varieties. Food Sci. Tech. Int. $14,95-102$.

Wilson, B., Strauss, C.R \& Williams, PJ., 1986. The distribution of free and glycosidically-bound monoterpenes among skin, juice, and pulp fractions of some white grape varieties. Am. J. Enol. Vitic. 37, 107-111. 